\title{
Mucosal Schwann-Cell Hamartoma Diagnosed by Using an Endoscopic Snare Polypectomy
}

\author{
Myoung Nam Bae, Jung Eun Lee, Sang Mook Bae, Eun Young Kim, Eun Ok Kim, Sung Hoon Jung, \\ Jung Hwan Oh, Ki Ok Min ${ }^{1}$ \\ Departments of Internal Medicine and ${ }^{1}$ Pathology, The Catholic University of Korea College of Medicine, Seoul, Korea
}

Colorectal polyps of mesenchymal origin are a rare group of colorectal disorders. A "mucosal Schwann-cell hamartoma," which is one type of polypoid lesion that originates from the mesenchyme, is a newly-proposed disease entity to be distinguished from the neurofibromas found in type-1 neurofibromatosis. This lesion is composed of pure Schwann-cell proliferation in the lamina propria and shows diffuse immunoreactivity for the S-100 protein. We report a case of a polypoid lesion of the colon with the features of this recently-proposed disease entity.

Keywords: Schwann cells; Hamartoma; Neurofibroma; Neuroma; Colon polyps

\section{INTRODUCTION}

Benign nerve sheath tumors of mesenchymal origin are relatively common lesions that arise from the skin and somatic soft tissue [1]. In contrast, involvement of the gastrointestinal tract is rare. Such tumors are clinically found in small polypoid lesions during colonoscopy. In recent years, these lesions of the colon have been increasingly detected due to the growth in the number of colonoscopies for colorectal cancer screening. The histological differential diagnosis of these neural lesions is broad and includes gastrointestinal stromal tumors, neurofibromas, mucosal neuromas, ganglioneuromas, and mucosal schwannomas [1,2].

Mucosal Schwann-cell hamartomas, which have no associations with inherited syndromes, have recently been categorized as a new disease to be distinguished from multiple neurofibromas associated with type-1 neurofibromatosis (NF1) [1]. Histologically, mucosal Schwann-cell hamartomas are composed of uniform spindle

Received: September 24, 2012 • Accepted: November 19, 2012 Correspondence to: Sung Hoon Jung, M.D.

Department of Internal Medicine, St. Paul's Hospital, The Catholic University of Korea College of Medicine, 180 Wangsan-ro, Dongdaemun-gu, Seoul 130-709, Korea

Tel: +82-2-958-2114, Fax: +82-2-968-7250

E-mail: shjung74@catholic.ac.kr

(c) 2013 The Korean Society of Coloproctology

This is an open-access article distributed under the terms of the Creative Commons Attribution NonCommercial License (http://creativecommons.org/licenses/by-nc/3.0) which permits unrestricted noncommercial use, distribution, and reproduction in any medium, provided the original work is properly cited. cells with elongated, tapering, or wavy nuclei, abundant dense eosinophilic cytoplasm, and indistinct cell borders with no nuclear atypia, pleomorphism, or mitoses [1]. The lesion shows strong and diffuse immunoreactivity for the S-100 protein. Although a proliferation of Schwann cells is observed, mucosal Schwann-cell hamartomas can be differentiated from schwannomas with no specific findings of verocay bodies, Antoni A and Antoni B regions, lymphoid cuffs, and lymphoid infiltrations [3]. We report, with a brief literature review, a case of a mucosal Schwann-cell hamartoma that was detected incidentally during colonoscopy for a routine check-up and was removed by using a snare polypectomy.

\section{CASE REPORT}

A 41-year-old woman was admitted to St. Paul's Hospital for a polypectomy of a colon polyp that had been detected by chance during colonoscopy for a routine check-up. She did not have any medical history of chronic diseases, including hypertension, diabetes, hepatitis, tuberculosis, and others. She had no history of alcohol consumption, smoking or medications. Her family history did not show any NF1 or gastrointestinal malignancies. Physical examination of the head, neck, lungs, heart, skin and other systems did not reveal any significant findings. She had normal bowel sound with neither abdominal tenderness nor any palpated abdominal mass. No freckles in the armpit or inguinal areas and no specific bone lesions were observed. Peripheral blood smear examination revealed a leukocyte count of $5,900 / \mathrm{mm}^{3}$, a hemoglobin level of $11.1 \mathrm{~g} / \mathrm{dL}$, and a platelet count of $236,000 / \mathrm{mm}^{3}$. The 
Volume 29, Number 1, 2013

result of coagulation was normal. A serum biochemical test revealed a total protein level of $6.8 \mathrm{~g} / \mathrm{dL}$, an albumin level of $4.4 \mathrm{~g} /$ $\mathrm{dL}$, an aspartate aminotransferase level of $14 \mathrm{IU} / \mathrm{L}$, an alkaline aminotransferase level of $9 \mathrm{IU} / \mathrm{L}$, a total bilirubin level of $0.7 \mathrm{mg} /$ $\mathrm{dL}$, a blood urea nitrogen level of $14 \mathrm{mg} / \mathrm{dL}$, and creatine level of $0.7 \mathrm{mg} / \mathrm{dL}$. On colonoscopic examination, a $0.8-\mathrm{cm}$ polyp with no erosion nor ulceration was found in the descending colon and was removed using a loop snare technique (Fig. 1). Histologically, the polyp contained a diffuse proliferation of spindle cells in the colonic mucosa, located in the lamina propria that entrapped the colonic crypts, and all cells were spindle shaped with elongated, tapering nuclei, abundant dense eosinophilic cytoplasm with indistinct cell borders, and no nuclear atypia, pleomorphism or mitoses (Fig. 2). By immunohistochemistry, the lesions showed

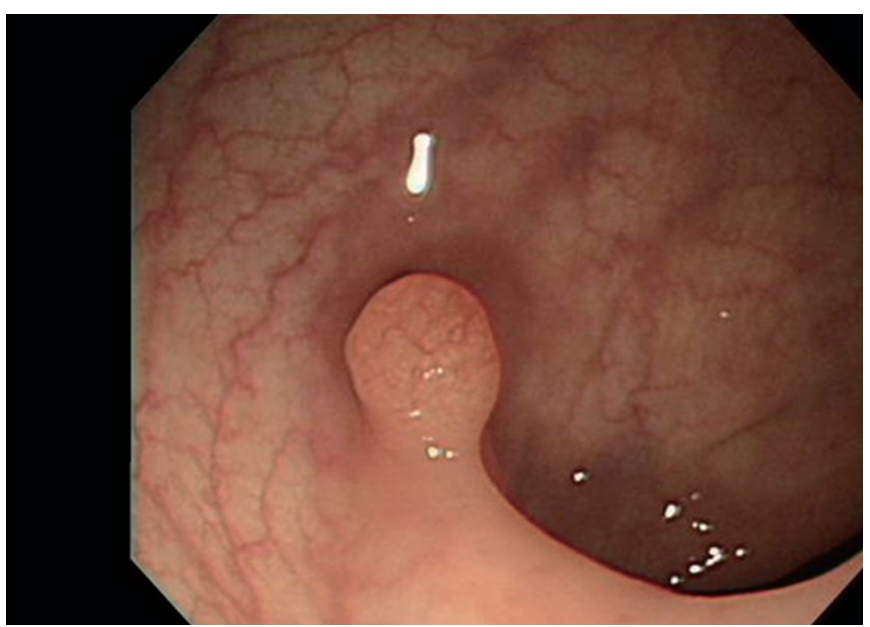

Fig. 1. Colonoscopic findings. A polyp $(0.6 \mathrm{~cm})$ at $28 \mathrm{~cm}$ from the anal verge with a normal overlying mucosa was found on colonoscopy. strong positivity for the S-100 protein and no activity for CD34, CD117 or for smooth muscle actin (Fig. 3).

The polyp was composed of pure fusiform Schwann cells. It was different from a neurofibroma of NF1, which shows a heterogeneous cellular composition, including Schwann cells, fibroblasts, perineural-like cells, and axons. Considering the histological findings, the immunohistochemical panel, and the absence of associated inherited syndromes, we diagnosed the polyp as a mucosal Schwann-cell hamartoma.

\section{DISCUSSION}

In recent years, colonoscopy has been performed more frequently for colorectal cancer screening, and the detection of polypoid lesions, including neural lesions, originating from the mesenchyme has increased. Among the polypoid lesions, colorectal polyps containing S-100 positive neural proliferations and lacking ganglion cells are called "neuromas" or "neurofibromas" [1]. Neurofibromas are benign tumors containing various cells, including Schwann cells, fibroblasts, perineural-like cells, and axons. In most cases, they are strongly associated with NF1 [4]. It has been estimated that up to $25 \%$ of gastrointestinal neurofibroma patients present with NF1, and the gastrointestinal neurofibroma is usually in the stomach or the small intestine, and is very rarely in the colon [1]. The lesions can be classified according to their growth patterns, which include solitary, diffuse, and plexiform [5]. Plexiform neurofibromas are a pathognomonic sign of NF1, and a solitary neurofibroma is rare $[1,5]$. A solitary neurofibromal colonic polyp without NF1 is very rare and has been reported in only 1 case in Korea and in 31 cases abroad [1-3, 6-8]. Recently, Gibson and Hornick [1] analyzed 26 cases of solitary colorectal polyps with pure Schwann-cell proliferation that were different from the neurofibromas found in NF1 and were not associated with inherited
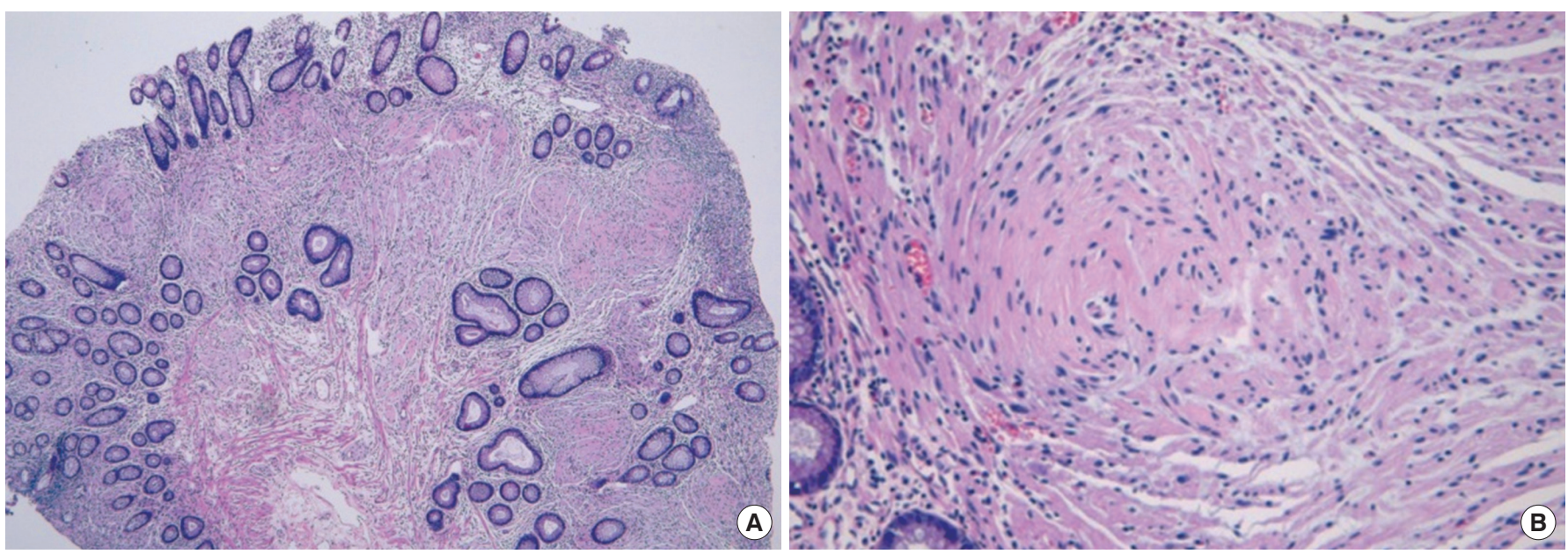

Fig. 2. Histological findings: (A) a diffuse proliferation of spindle cells in the colonic mucosa, located in the lamina-entrapping adjacent crypts $(\mathrm{H} \& \mathrm{E}, \times 40)$, and (B) a diffuse cellular proliferation of uniform bland spindle cells with elongated, tapering nuclei, abundant, dense eosinophilic cytoplasm, and indistinct cell borders $(\mathrm{H} \& \mathrm{E}, \times 400)$. 

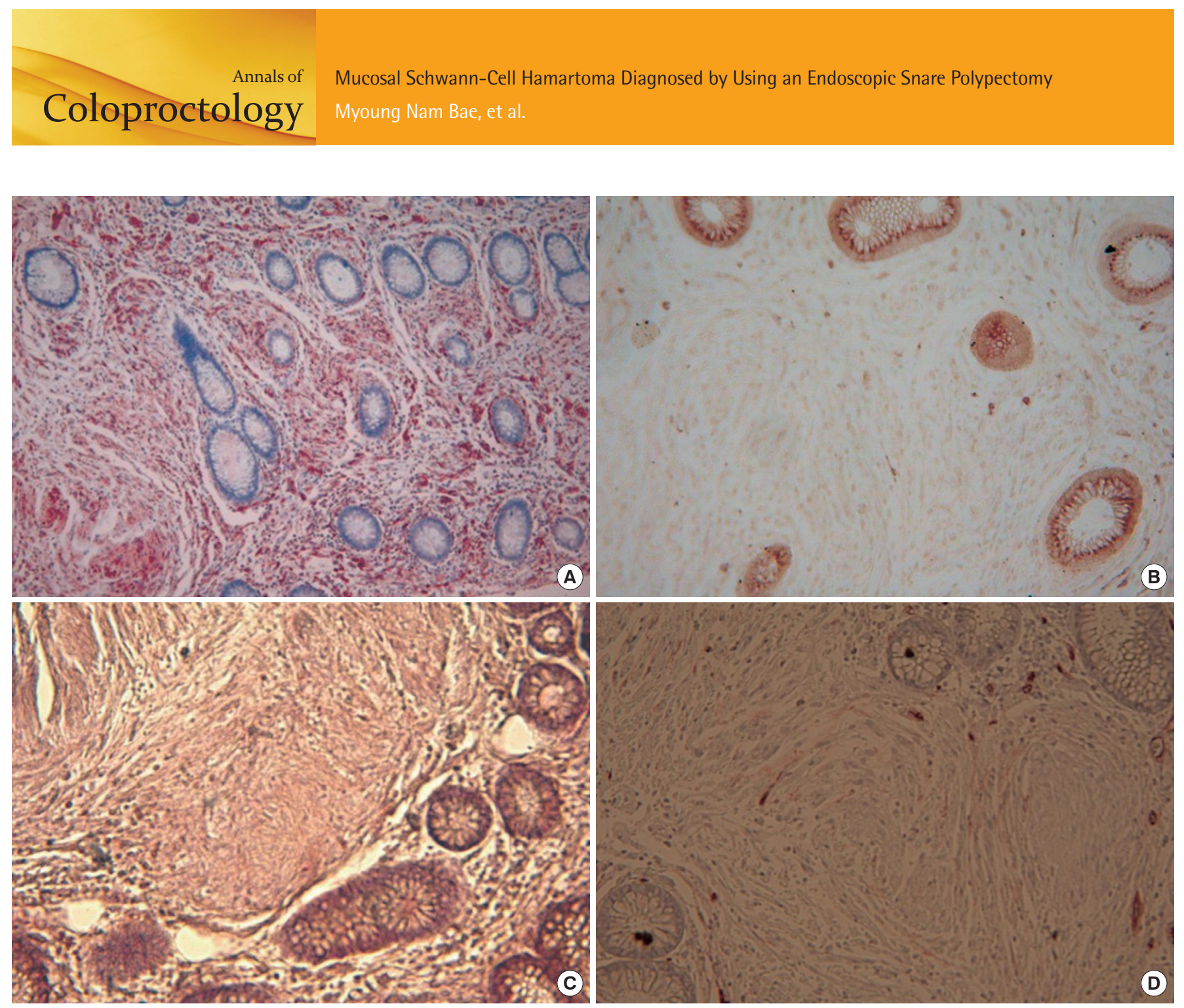

Fig. 3. The lesion shows a pure Schwann-cell immunophenotype: (A) strong positive immunoreactivity for S-100 protein ( $\times 200)$, (B) negative for CD117 ( $\times 200)$, (C) negative for smooth muscle actin $(\times 200)$ and $(\mathrm{D})$ negative for CD34 $(\times 200)$. In $\mathrm{D}$, the structure stained brown is a blood vessel.

syndromes. This new disease entity was designated as a mucosal Schwann-cell hamartoma to avoid confusing it with the neurofibromas found in hereditary diseases.

The histological differential diagnosis of a mucosal Schwann-cell hamartoma includes a gastrointestinal stromal tumor, a neurofibroma, a mucosal neuroma, a ganglioneuroma, and a mucosal schwannoma [1-3]. Gastrointestinal stromal tumors are frequently detected in the form of subepithelial tumors in the stomach or small intestine, but are rarely found in the colon. The tumors are positive for CD117 in immunohistochemical staining [2, 9]. Neurofibromas with NF1 have heterogenous cellular components, including Schwann cells, fibroblasts, perineural-like cells, and axons. Although a positive reaction for the S-100 protein is seen in immunohistochemical staining, the staining is uneven. In addition, neurofibromas contain scattered axons. On the other hand, a mucosal Schwann-cell hamartoma is composed of single Schwann cells without other cells, such as axons or fibroblasts, and is uniformly stained for S-100 in immunohistochemical staining [1].
Mucosal neuromas are mainly detected on the lips and the tongue and are very rarely found in the gastrointestinal tract. The lesions are highly associated with multiple endocrine neoplasia, type $2 \mathrm{~B}$ [10]. Mucosal neuromas, which are composed of hyperplastic bundles of nerve fibers and axons, can be histologically distinguished from a mucosal Schwann-cell hamartoma [1]. A solitary ganglioneuroma is often found as a scattered form that is not associated with hereditary diseases. In colonoscopy, it is usually detected as a small sessile polyp and measures less than $1 \mathrm{~cm}$ [11]. The histological detection of gangliocytes enables its differentiation from a mucosal Schwann-cell hamartoma $[1,2]$. A mucosal perineurioma shows a negative reaction for the S-100 protein in immunohistochemical staining, as well as a partial, weakly positive reaction to the epithelial membrane antigen $[1,2]$. Mucosal schwannomas are often detected in the stomach and are rarely found in the colon. Histologically, schwannomas typically show Antoni A areas with a high cell density, Antoni B areas with a low cell density, and characteristic peripheral lymphoid cuffs $[1,12]$. The character- 
istics of a schwannoma, such as Antoni A and Antoni B regions, lymphoid cuffs, and lymphoid infiltrations, are not observed in a mucosal Schwann-cell hamartoma [2].
The polyp in our case contained a diffuse proliferation of spindle cells in the colonic mucosa, located in the lamina propria that entrapped the colonic crypts, and all cells were spindle shaped with

Table 1. Clinical and endoscopic findings of a mucosal Schwann-cell hamartoma

\begin{tabular}{|c|c|c|c|c|c|c|c|c|}
\hline Case & $\begin{array}{l}\text { Age } \\
(y r)\end{array}$ & Sex & Location & $\begin{array}{l}\text { Size } \\
(\mathrm{mm})\end{array}$ & Indication & Other finding & $\mathrm{F} / \mathrm{U}(\mathrm{mo})$ & Ref. \\
\hline 1 & 86 & Female & SC & 3 & Screening & 6 Adenomas & NED (55) & 1 \\
\hline 2 & 79 & Female & DC & 2 & Screening & None & NED (212) & 1 \\
\hline 3 & 63 & Female & DC & 2 & Screening & None & NA & 1 \\
\hline 4 & 54 & Female & SC & 2 & Diarrhea & None & NED (190) & 1 \\
\hline 5 & 62 & Female & Rectum & 2 & Screening & $\begin{array}{c}2 \text { Adenomas, } \\
2 \text { hyperplastic polyps }\end{array}$ & NED (75) & 1 \\
\hline 6 & 46 & Male & RS & 3 & Screening & None & NED (17) & 1 \\
\hline 7 & 49 & Female & DC & 1 & Screening & 3 Adenomas & NED (79) & 1 \\
\hline 8 & 52 & Male & $\mathrm{TC}$ & 3 & Screening & $\begin{array}{c}5 \text { Adenomas, } \\
1 \text { hyperplastic polyp }\end{array}$ & NED (28) & 1 \\
\hline 9 & 51 & Male & Rectum & 2 & Rectal bleeding & None & NED (62) & 1 \\
\hline 10 & 63 & Female & $\mathrm{SC}$ & 2 & Rectal bleeding & None & NA & 1 \\
\hline 11 & 68 & Female & $\mathrm{TC}$ & 3 & Diarrhea & None & NED (44) & 1 \\
\hline 12 & 69 & Male & $\mathrm{AC}$ & 2 & Screening & 2 Adenomas & NA & 1 \\
\hline 13 & 52 & Female & $\mathrm{DC}$ & 3 & Screening & None & NED (33) & 1 \\
\hline 14 & 54 & Female & $\mathrm{SC}$ & 5 & Screening & None & NED (3) & 1 \\
\hline 15 & 85 & Female & SC & 1 & Anemia & None & NED (29) & 1 \\
\hline 16 & 59 & Male & SC & 5 & Screening & 1 Adenoma & NA & 1 \\
\hline 17 & 62 & Male & $A C$ & 6 & Screening & $\begin{array}{c}1 \text { Adenoma, } \\
2 \text { hyperplastic polyps }\end{array}$ & NA & 1 \\
\hline 18 & 58 & Female & $\mathrm{DC}$ & 2 & Screening & None & NA & 1 \\
\hline 19 & 61 & Male & $\mathrm{SC}$ & 3 & Screening & None & NA & 1 \\
\hline 20 & 78 & Female & SC & 1 & Screening & 4 Adenomas & NED (13) & 1 \\
\hline 21 & 50 & Male & $\mathrm{DC}$ & 1 & Screening & 1 Hyperplastic polyp & NA & 1 \\
\hline 22 & 88 & Female & $\mathrm{SC}$ & 2 & Gl bleeding & None & NA & 1 \\
\hline 23 & 63 & Male & $\mathrm{DC}$ & 2 & NA & 2 Hyperplastic polyps & Recent case & 1 \\
\hline 24 & 54 & Female & $\mathrm{SC}$ & 2 & Screening & None & Recent case & 1 \\
\hline 25 & 50 & Male & SC & 3 & Screening & None & Recent case & 1 \\
\hline 26 & 50 & Female & $\mathrm{SC}$ & 2 & NA & None & Recent case & 1 \\
\hline 27 & 67 & Female & $\mathrm{DC}$ & 3 & $\begin{array}{c}\text { Regular F/U colonoscopy } \\
\text { due to tubulovillous adenoma }\end{array}$ & None & NA & 2 \\
\hline 28 & 60 & Female & $\mathrm{RS}$ & 5 & OB positive & None & NA & 3 \\
\hline 29 & 34 & Male & SC & 4 & $\begin{array}{l}\text { Loose stool and abdominal } \\
\text { discomfort }\end{array}$ & None & NED (6) & 4 \\
\hline 30 & 53 & Male & $\mathrm{TC}$ & 22 & $\begin{array}{l}\text { Hematochezia and abdominal } \\
\text { pain }\end{array}$ & Intussusception & ARDS, death & 6 \\
\hline 31 & 65 & Female & $\mathrm{DC}$ & 10 & Bloody diarrhea and fever & Hepatic flexure segmental colitis & NA & 7 \\
\hline 32 & 59 & Male & $\mathrm{TC}$ & 3 & Screening & 1 Adenoma & Lymphoma, death & 8 \\
\hline
\end{tabular}

F/U, follow-up; Ref, reference; SC, sigmoid colon; NED, no evidence of disease; DC, descending colon; NA, not available; TC, transverse colon; AC, ascending colon; Gl, gastrointestinal; $\mathrm{RS}$, rectosigmoid colon; $\mathrm{OB}$, occult blood; $\mathrm{ARDS}$, acute respiratory distress syndrome. 
elongated, tapering nuclei, abundant dense eosinophilic cytoplasm with indistinct cell borders, and no nuclear atypia, pleomorphism or mitoses. Axons and gangliocytes were not observed in the lesion. A positive reaction to the $\mathrm{S}-100$ protein was seen in immunohistochemical staining. In contrast, negative reactions for CD117, smooth muscle actin, and CD34 were exhibited. The patient had no related NF1 or other hereditary diseases. Therefore, the polyp was diagnosed as a mucosal Schwann-cell hamartoma according to the proposal of Gibson and Hornick [1]. However, the clinical significance of a mucosal Schwann-cell hamartoma has not yet been established.

The author reviewed the literature by searching for neuroma, neurofibroma, neurofibromatosis, spindle cell, colorectal polyp and others in PubMed, LISTA, and KoreaMed. Table 1 shows the lesions occurring in the colon and rectum that showed solitary single spindle cell proliferation, were not associated with hereditary diseases, revealed a positive reaction to the S-100 protein in immunohistochemical staining, and showed no axons or ganglion cells [1-4, 6-8]. A total of 32 cases have been reported. The mean age of patients was 60.7 years old, 54.5 years in males and 65 years in females. The ratio of males to females was 1:1.46. A mucosal Schwann-cell hamartoma usually produces no symptoms and is detected by chance in $59 \%$ of the cases during colonoscopy performed as routine screening, but the patient may present with diarrhea (12\%), melena (12\%), abdominal pain or abdominal discomfort (6\%), and anemia (3\%). Ten patients of total 32 cases (31.25\%) had another colon polyp which was an adenomas or a hyperplastic polyp. Intussusception was observed in 1 of the 32 cases (3.12\%).

Among all cases, 14 (43\%) were followed up. Subsequently, no other diseases or characteristics related with hereditary diseases were seen during follow-up for an average of 48 months. In a case report by Hindy [8], a patient died due to a lymphoma. In a case report by Abramson [6], the patient visited the emergency department with melena and underwent surgery due to intussusception. He died of adult respiratory distress syndrome related to postoperative pneumonia. In the two cases of death, there was no direct association between the mucosal Schwann-cell hamartoma and the cause of death.

A mucosal Schwann-cell hamartoma is very rare entity. Patients with the lesion have not been associated with NF1, and malignant transformation has not been reported. However, its clinical significance has yet to be established. Thus, a need exists for close and continuous follow-up of patients with a mucosal Schwann-cell hamartoma.

\section{CONFLICT OF INTEREST}

No potential conflict of interest relevant to this article was reported.

\section{REFERENCES}

1. Gibson JA, Hornick JL. Mucosal Schwann cell "hamartoma": clinicopathologic study of 26 neural colorectal polyps distinct from neurofibromas and mucosal neuromas. Am J Surg Pathol 2009; 33:781-7.

2. Rocco EG, Iannuzzi F, Dell'Era A, Falleni M, Moneghini L, Di Nuovo F, et al. Schwann cell hamartoma: case report. BMC Gastroenterol 2011;11:68.

3. Pasquini P, Baiocchini A, Falasca L, Annibali D, Gimbo G, Pace F, et al. Mucosal Schwann cell "Hamartoma": a new entity? World J Gastroenterol 2009;15:2287-9.

4. Kim KO, Jang BI, Moon HJ, Lee SH, Lee JY, Lee KH, et al. A solitary colonic neurofibroma in a patient without neurofibromatosis. Korean J Gastrointest Endosc 2008;36:44-7.

5. Hochberg FH, Dasilva AB, Galdabini J, Richardson EP Jr. Gastrointestinal involvement in von Recklinghausen's neurofibromatosis. Neurology 1974;24:1144-51.

6. Abramson LP, Orkin BA, Schwartz AM. Isolated colonic neurofibroma manifested by massive lower gastrointestinal bleeding and intussusception. South Med J 1997;90:952-4.

7. Panteris V, Vassilakaki T, Vaitsis N, Elemenoglou I, Mylonakou I, Karamanolis DG. Solitary colonic neurofibroma in a patient with transient segmental colitis: case report. World J Gastroenterol 2005;11:5573-6.

8. Hindy P, Parvin R, Hanna K, Andrawes S, Gress F, Goodman A. An isolated neurofibromal polyp of the colon. Case Rep Gastroenterol 2012;6:58-62.

9. Laurini JA, Carter JE. Gastrointestinal stromal tumors: a review of the literature. Arch Pathol Lab Med 2010;134:134-41

10. Lewin MR, Dilworth HP, Abu Alfa AK, Epstein JI, Montgomery E. Mucosal benign epithelioid nerve sheath tumors. Am J Surg Pathol 2005;29:1310-5.

11. Shekitka KM, Sobin LH. Ganglioneuromas of the gastrointestinal tract: relation to Von Recklinghausen disease and other multiple tumor syndromes. Am J Surg Pathol 1994;18:250-7.

12. Miettinen M, Shekitka KM, Sobin LH. Schwannomas in the colon and rectum: a clinicopathologic and immunohistochemical study of 20 cases. Am J Surg Pathol 2001;25:846-55. 